\title{
Threatening Health Impacts and Challenging Life of Sanitary Workers
}

\author{
Gomathi P. ${ }^{1}$, Kamala K. ${ }^{2}$ \\ 1Department of Nursing, Vinayaka Mission's College of Nursing, Karaikal, Puducherry, India. ${ }^{2}$ Department of Nursing, \\ Vinayaka Mission's Research Foundation, (Deemed to Be University), Salem, Tamil Nadu, India.
}

\section{ABSTRACT}

\section{BACKGROUND}

The term sanitation refers to adequate treatment and disposal of human excreta and sewage, and provide clean drinking water. The aim of sanitary system is protecting human health by providing safe and clean environment. It helps to prevent transmission of diseases which are spreading through faecal-oral route. Sanitary workers are protecting the society from diseases such as diarrhoea, ascariasis, cholera, hepatitis, poliomyelitis, schistosomiasis and trachoma with their effective services.

Sanitary services are given by the sanitary workers for the betterment of human health. Sanitary workers are doing the work such as sweeping streets, collecting waste from house to house and streets, latrine or pit cleaning, cleaning school toilets, public toilets, toilets of municipalities, government and private offices, operating waste collecting trucks, management of faecal sludge, desludging the septic tank, cleaning sewer, cleaning manholes, cleaning sewage treatment plants and handling waste water and sludge at sewage treatment plants.

Sanitary workers are the key persons responsible for cleanliness of the country. At the same time, they are facing many challenges such as (i) issues related to their health and safety: cuts, injuries, musculoskeletal problems, respiratory problems, gastro intestinal problems and infectious diseases like gastroenteritis, diarrhoea, cryptosporidiosis, giardiasis, hepatitis A, hepatitis B, leptospirosis, salmonellosis, typhoid fever and tetanus.; (ii) legal and institutional issues: poor enforcement of law, lack of standard operating procedures, poor legal protection and workers safety which is influenced by the availability of equipment and materials used for doing the work and also by customers and employers; (iii) insecurity in financial status and social issues; social stigma like intergenerational discrimination.

Sanitary workers are not concentrating on their own health and nutritional status due to lake of awareness. There is a need to enrich the knowledge of workers regarding prevention of health problems, protection from health issues and promotion of their health. The employer has to ensure that workers have undergone training before placement in the job and also, they must be provided with proper guidelines. Workers must get adequate facilities in the working area. Sanitary workers must be provided with personal protective equipment and insisted to use it properly. Regular medical check-up, vaccination and follow up are very important to protect the sanitary workers.

\section{KEY WORDS}

Sanitary Workers, Health Problems
Corresponding Author:

Gomathi. P,

Vinayaka Mission's College of Nursing, Karaikal, Puducherry, Tamilnadu, India. E-mail: gomzselva@gmail.com

DOI: $10.14260 / \mathrm{jemds} / 2020 / 669$

How to Cite This Article:

Gomathi P, Kamala K. Threatening health impacts and challenging life of sanitary workers. J. Evolution Med. Dent. Sci. 2020;9(41):3055-3061, DOI: 10.14260/jemds/2020/669

Submission 13-04-2020,

Peer Review 29-06-2020,

Acceptance 06-07-2020,

Published 12-10-2020.

Copyright (C) 2020 JEMDS. This is an open access article distributed under Creative Commons Attribution License [Attribution 4.0 International (CC BY 4.0)] 


\section{BACKGROUND}

World Health Organization defines the term "Sanitation" as the provision of facilities and services for the safe disposal of human excreta and also refers to the maintenance of hygienic conditions, through services such as garbage collection and waste disposal. [1] Sanitary workers are rendering their services to the public in many ways such as cleaning filthy toilets, septic tanks, streets, roads, beaches etc. The Sanitary workers are always exposed to vulnerable surroundings and also, they have higher risk for accidents, injuries, infections and other health impacts such as musculoskeletal problems, gastrointestinal problems, respiratory problems, dermatological problems etc. The statistics shows that more than 5 million sanitary workers are in India among them 2.5 million workers were exposed to various occupational hazards.[2][3] Health impacts on sanitary workers are caused by improper handling of different types of waste such as liquid waste, solid rubbish (plastic waste, paper / card waste, Tins and metals, ceramics and glass) organic waste, recyclable rubbish, hazardous waste and also biodegradable and nonbiodegradable waste.[4]

Dr. Sanjay Sujitrajan Das conducted a cross sectional survey study among 300 waste handlers of Surat Municipal Corporation. He has collected the data by using semi structured interview schedule and assessed the morbidity level. The researcher authenticated that majority of the workers suffered with injuries (77.7\%), musculoskeletal disorders (71\%), respiratory infections (62.3\%) ophthalmic problems, (36.3\%) and dermatological problems (30\%). The researcher identified that the risk of health problems are more common among the workers who are new to the job, untrained workers, unhygienic waste handlers and persons who are not using personal protective equipment.[5]

$\mathrm{N}$. Rajavel conducted a descriptive study among women sanitary workers who have faced health problems at Thanjavur. The researcher used census method to collect the data and he has selected all the women sanitary workers working at Municipal Corporation of Thanjavur. He has collected socio demographic data by using semi structured interview schedule and assessed the quality of life. The study shows that $60 \%$ of the samples are facing sex discrimination. Majority of the women (81\%) were illiterate and $67 \%$ of women sanitary workers are having skin diseases and the study shows that there was a significant relationship between the age of women and quality of life of the sanitary workers.[6]

M. D. Saravana Balaji, R. Abinaya et al (2018) explored a study to assess the occupational health status of sewage and sanitary workers in Avaniyapuram at Madurai District. The study results show that (i) the total count of polymorphs ranges from $64-70 \%$ which is indicative that they had lung infection. (ii) The results show that the values of haemoglobin ranges from 7 to $10 \mathrm{gms}$ and it indicates that all the samples were having mild to moderate anaemia.[7] Dr. Lourdes Poobala Rayan (2016) conducted a descriptive and analytical study to assess the problems among 460 sanitary workers of Tirunelveli Corporation. The data was collected by using structured interview schedule. The study result shows that majority of the respondents are getting insufficient salary, they are unable to meet out their children's education requirements, not able to meet hospital expenses, unable to take healthy foods and not able to meet basic needs. ${ }^{[8]}$

Somsiri Decharat (2017) conducted a cross sectional descriptive study to evaluate the prevalence of adverse health effects among 114 municipal solid waste workers of 5 sanitary landfill areas of Southern Thailand. The data was collected by using questionnaire. The study result shows that there were lot of health problems such as musculoskeletal problems $(65.8$ $\%)$, respiratory problems (47.4\%), skin problems (58.8\%), nail problems (45.6\%), eye problems (20.2\%) and gastrointestinal problems (42.1\%). This study concluded that there was a strong relationship between municipal solid waste work and adverse health effects of sanitary workers. The study insisted on education regarding good personal hygiene and use of personal protective equipment's to reduce adverse health effects among sanitary workers.[9]

Priyanka. V. Patil and R.K. Kamble conducted a descriptive study to identify the occupational health hazards in sanitary workers in Chandrapur city, India. The data was collected by using structured questionnaire among 20 workers out of 198 sanitary workers. Duration of the study was from November 2015 to January 2016. The results of the study explored that $85 \%$ of the workers suffered with musculoskeletal disorders, $65 \%$ of the workers were exposed to harmful gases, $45 \%$ of the sample suffered with respiratory problems, $40 \%$ had head ache during the study, 35\% had dermatological problems, $10 \%$ suffered with gastrointestinal disorders and $10 \%$ had leptospirosis.[10]

\section{HEALTH IMPACTS ON SANITARY WORKERS}

\section{Physiological Health Issues}

Sanitary workers are prone to face certain health problems due to their working condition. The physiological health issues include injuries, gastrointestinal disorders, musculoskeletal disorders, respiratory disorders, dermatological disorders, ophthalmic disorders and infections such as gastroenteritis, $E$. coli diarrhoea, cryptosporidiosis, giardiasis, hepatitis $\mathrm{A}$, hepatitis B, leptospirosis, salmonellosis, typhoid fever and tetanus.

\section{a. Accidents and Injuries}

Accidents and injuries are more common among sanitary workers who are working with lack of attention towards the work and who have not undergone adequate training and among the workers not using proper personal protective measures.[11][12][13][14]

\section{b. Musculoskeletal Disorders}

Musculoskeletal symptoms such as low back ache, wrist pain, neck pain, knee pain are the regular problems of sanitary workers and these are caused by heavy work load, frequent bending and straightening up the body, improper positioning while handling waste materials and poor nutritional status.[15][16][17][18] 


\section{c. Gastrointestinal Disorders}

Nausea, vomiting and diarrhoea are associated with exposure to endotoxins and ingestion of pathogenic organisms such as Aspergillus fumigates, Pseudomonas aeruginosa and Legionella pneumophila. Gastroenteritis is caused by ingestion of microbial pathogens such as Cryptosporidium and Rotavirus. Unhygienic eating habits in the working area can cause intestinal worm infestation.[12][19][20][21]

\section{d. Respiratory Disorders}

Hazardous wastes consist of more toxic gases such as methane, carbon monoxide and hydrogen sulphide. Inhalation of toxic gases causes health effects such as throat infection, cough, difficulty in breathing and bronchitis. ${ }^{[22]}$ Excessive inhalation of hydrogen sulphide may cause anoxia, asphyxia and even death. Findings of several studies indicate that cigarette smoking is a major risk factor in the development of chronic bronchitis, in an addition to the previous studies indicates that besides cigarette smoking, other factors too constitute a risk. These include exposure to fumes, silt and sewer gases, including methane, hydrogen sulphide, ammonia, carbon monoxide, sulphur dioxide and nitrogen oxides, which are more harmful than smoking. [23][24][25][26][27]

\section{e. Dermatological Disorders}

Presence of microorganisms and chemicals in the sewage are causing skin infections and allergic reactions. Presence of sharp instruments in the waste may cause cuts, injury, laceration and wound.[28][29]

\section{f. Ophthalmic Problems}

Sanitary workers may experience burning sensation in the eyes, watery eyes, redness, irritation and blurred vision due to exposure to pollutants such as chemicals, gases, acids and bio active irritants.[30][31]

\section{g. Infections}

Infections among sanitary workers caused by unhygienic habits such as eating, drinking, and smoking with contaminated hands and not using personal protective equipment. The following infections are experienced by the sanitary workers in various locations and in various circumstances:[32][33]

\section{Gastroenteritis}

If the sanitary workers are not following the hygienic practices and if they ingest the viruses such as rotaviruses and adenoviruses it leads to gastroenteritis. The person may experience the signs and symptoms such as abdominal pain, fever, vomiting and watery diarrhoea.[34][35]

\section{E. coli Diarrhoea}

Diarrhoea is caused by E. coli bacteria among sanitary workers who are handling contaminated sewage water and other waste materials. The signs and symptoms of diseases are nausea, vomiting, abdominal cramps, fever and bloody diarrhoea. This disease is commonly affecting the persons with low immunity.[36][37]

\section{Cryptosporidiosis}

Cryptosporidiosis is one of the parasitic infections caused by Cryptosporidium parvum. This parasite has spread all over the world and it is causing water borne disease. If the sanitary workers are exposed to this organism, they will show the symptoms of nausea, vomiting, abdominal cramps, stomach upset, fever and diarrhoea.[38]

\section{Giardiasis}

Entry of microscopic pathogen giardia lamblia into the gastrointestinal system leads to giardiasis. It is one of the water-borne disease. The signs and symptoms are stomach upset, cramps in the stomach and watery stools.[38]

\section{Hepatitis A}

Hepatitis $A$ is an infectious disease caused by hepatitis A virus. It is one of the vaccine preventable diseases. Generally, hepatitis A is a self-limiting disease. The symptoms of hepatitis A are nausea, vomiting, fever, diarrhoea, fatigue, loss of appetite and jaundice.[38][39]

\section{Hepatitis B}

The employees who are exposed to sewage are having the chance of getting hepatitis B infection. Workers exposed to sewage are recommended for hepatitis B vaccination.[40][41]

\section{Leptospirosis}

It is one of the occupational diseases affecting the sanitary workers who are handling animal excreta. The causative organism is leptospira and it is carried by the rodents. This organism is present in the urine of rodents and other animals and the sanitary workers have the potential to get the infection. Ambekar et al conducted a study among sewer workers at Pune and the study showed that out of 78 workers $16.6 \%$ are prevalent to leptospirosis infection. ${ }^{[42][43]}$

\section{Salmonellosis}

Salmonellosis is an infectious disease caused by Salmonella type bacteria. The infection is transmitted by contaminated food. If the sanitary workers are not following hygienic practices and when they consume food with contaminated hands it leads to salmonellosis. The common symptoms are abdominal cramps, vomiting, fever and diarrhoea. The disease can be prevented by hygienic preparation and eating of food.[38] 


\section{Typhoid Fever}

Typhoid fever is caused by Salmonella typhi and Salmonella paratyphi. This disease commonly affects the intestinal tract and shows the signs and symptoms of headache, fatigue, loss of appetite, cough, high fever and stomachache. The affected person may carry the organism after the recovery and organism will shed in the stool. Proper hygienic practices will reduce the risk of this disease and the affected persons should not share their food with others:[38]

\section{Tetanus}

Sanitary workers are prone to tetanus toxoid infection as they clear garbage waste every day. The waste may consist of sharp metals, glass pieces etc. If the workers fail to take precautionary measures while collecting waste, it may lead to cuts and injuries. They must be immunized with Tetanus Toxoid vaccine periodically to avoid these types of adverse effects.[38]

\section{Psychological Issues}

Due to heavy workload, the sanitary workers are undergoing lot of psychological impacts such as stress and depression. The psychological problems arise because of failure to adapt to the working environment, lack of job satisfaction, job insecurity, poor relationships among workers, lack of communication, emotional disturbances, dual role at home and working environment and sexual harassment for women in the work place. ${ }^{[44][45]}$

\section{CHALLENGES FACED BY THE SANITARY WORKERS}

Sanitary workers are providing an essential public service to the people. They are always doing financially precarious work with low payment and other benefits. There is no strong legal protection, standard operating procedures, laws and policies for protecting the sanitary workers. A comparative analysis was undertaken and informed the World Health Organization (WHO), International Labour Organization (ILO), Water Aid and the World bank to take initiatives on sanitary workers. The analysis showed that the following challenges are faced by the sanitary workers. [46][47][48][49]

\section{Financial Challenges}

- Irregular payment.

- Temporary or informal job.

- Low income.

- Vulnerable to extortion.

\section{Social Challenges}

- Social discrimination and social stigma.

- Allocation of work as per caste hierarchy.

- Intergenerational transmission of discrimination.

- $\quad$ Lack of dignity.

\section{Legislative Challenges}

- Sanitary workers are vulnerable to many problems because of lack of legal protection and rules.

\section{SAFEGUARDING THE SANITARY WORKERS}

\section{Training}

Sanitary workers must undergo adequate training before placement of the job. Periodic training to be given to the workers regarding hygienic practices, safe handling of waste, appropriate use of personal protective equipment's, early identification of diseases and regular medical check-up. ${ }^{[50][51]}$

\section{Hygienic Practices}

- Hand hygiene: After handling waste the hands must be washed thoroughly with soap and water.

- Avoid handling of waste with bare hand and wear gloves.

- Wash hands thoroughly with soap and water before and after drinking, eating and smoking.

- $\quad$ Cut short the nails to reduce the risk of infection by accumulation of dirt.

- Touching the face, eyes, nose, mouth, ears, cuts and wounds with contaminated hands to be avoided.

- Restrict tobacco chewing and smoking during the time of waste handling.

- Remove the personal protective equipment's and ensure hand hygiene before eating.

- Keep away the working clothes and other PPEs while eating.

- Remove the personal protective equipment's such as rubber boots and clothing and wash them thoroughly, dry it and store it properly after the working time.[51][52]

\section{Use of Personal Protective Equipment}

Sanitary workers must use the appropriate PPEs while handling waste.[51][52]

- Protect the hands from contamination by sewage and human waste by wearing gloves.

- Eyes to be protected from splashes of waste or sewage by using goggles.

- The personal clothing to be protected by liquid repellent coveralls.

- Use of face mask to protect the mouth and nose.

- Rubber boots help to protect the feet from cuts, injuries and contact with waste or sewages.
4. Vaccination infectious diseases
- Hepatitis A vaccine.
- Hepatitis B vaccine.
- Typhoid vaccine.
- Tetanus toxoid vaccine.

Sanitary workers are prone to get infectious disease due to exposure to harmful waste materials. The following vaccines are suggested to the waste handlers to protect them from 


\section{Other Measures to Protect the Health of Sanitary Workers}

Promotion and maintenance of physical, mental and social wellbeing of sanitary workers are to be improved. The WHO committee recommended the following for the protection of general health of the workers.

\begin{abstract}
Nutrition
Adequate nutrition is one of the fundamental requirements for optimal health and effective protection. Adequate nutritional status is essential for workers development. A well-nourished diet is required for workers for successful economic and social development. Malnutrition is one of the factors which leads to poor health status. Malnutrition leads to low immune system of the body that gives way for lot of infections. All the facilities are to be provided for the workers to improve their nutritional status and prevention of deficiency diseases.[53][54]
\end{abstract}

\section{Provision of Safe Water Supply}

Make sure that the sanitary workers to be provided with adequate safe drinking water to control water borne diseases. ${ }^{[53]}$

\section{Regulation in Working Hours and Regular Salary and Legal Protection}

Sanitary workers are doing financially precarious work with low payment and other benefits. There is no strong legal protection, standard operating procedures, laws and policies for protecting the sanitary workers. These problems can be overcome by the following ways: (i) Policy reformation, regulation and legislation to be improved to protect the sanitary workers. (ii) Operational guidelines, standard operating procedures, training for workers, use of latest technology and use of personal protective equipment's to be assessed periodically and to be adopted. (iii) Unions and Associations - promote the empowerment and protect the rights of sanitary workers with the help of unions and associations.[55]

\section{Psychological and Behavioural Changes}

Ensure that the workers must be free from anxiety and depression during working hours and avoid the habits of alcohol consumption, smoking, chewing of pan masala, gutkha, etc. [56]

\section{Reducing Conflicts among Workers}

Make sure that the sanitary workers are adapted to the working environment and maintain good relationship with the co-workers.

\section{Adequate Support from Family Members}

Family members should not show any discrimination towards the sanitary workers and they should keep them mentally stable. They must be recognized with love and affection by the family members. Female sanitary workers have to balance the domestic roles as well as occupational roles simultaneously and they must be supported by the family members.[57][58][59][60]

\section{Implementation of Regular Health Check Up}

Pre- placement examination is essential. It is done at the time of employment and it includes family occupational and social history, thorough physical examination, blood and urine examination, testing of vision and special tests for communicable diseases. The periodic medical check-up of sanitary workers is very necessary because they are handling dangerous and toxic waste material regularly and exposed to toxic gases:[61][62]

\section{Make Them Aware of Health Schemes}

Sanitary workers can be benefited by health schemes such as Employee state insurance scheme. But these schemes are available only to the permanent workers.

\section{Health Education}

Health education to be given on promotion of health, prevention of diseases and protection from harms by using audio visual aids such as posters, pamphlets, notices, flash cards, audio recordings, video teaching etc.

\section{CONCLUSIONS}

Sanitary workers are performing their vital role for healthy life of public. We have noticed that they are rendering their irreplaceable services to the community without any hesitation in many circumstances (e.g. corona outbreak). Sanitary workers should be provided with adequate training, health education, salary, uniform and other facilities. They must be respected and treated with dignity and should be ensured a healthy living.

Financial or other competing interests: None.

Disclosure forms provided by the authors are available with the full text of this article at jemds.com.

\section{REFERENCES}

[1] Sanitation: https://en.wikipedia.org/wiki/Sanitation

[2] Bhatnagar N. The harsh reality of life for India's 5 million sanitation workers. Quartz India 2018.

[3] Pushparani JP, Chitra A, Kalpana J. A cross-sectional study to assess the health profile of street sweepers and sanitary workers in a zone of Greater Chennai, Corporation, Tamil Nadu, India. International Journal of Community Medicine and Public Health 2018;5(10):4362-57.

[4] Types of waste: rubbish removals. 4 waste removals Pvt Ltd 2016.

[5] Das SS. Occupational health problems among door to door solid waste handlers in Surat city, Gujarat. J Community Med Health Educ 2013;3(4):93. 
[6] Rajavel N. Health problems faced by women sanitary workers in Thanjavur Town- a study. Indian Journal of Applied Research 2015;5(12):30-2.

[7] Balaji S, Abinaya R, Sooriyakala G, et al. A study of the occupational health status of sewage and sanitary workers in Avaniyapuram at Madurai District. J Environ Nanotechnol 2018;8(1):42-6.

[8] Rayen LP, Nisee TJ. A study on the status of sanitary workers in Tirunelvelli Corporation of Tamilnadu. International Journal of Multidisciplinary Research 2016;2(4):63-72.

[9] Decharat S. Prevalence of adverse health effects among municipal solid waste workers, Southern Thailand. International Journal of Occupational Hygiene 2017;9(4):186-91.

[10] Patil PV, Kamble RK. Occupational health hazards in sanitary workers of Chandrapur city, Central India. International Journal of Environment 2017;6(3):15-24.

[11] Municipal workers face privatization, cuts, precarious work, pension attacks, and tough bargaining. Canadian Union of Public Employees 2015.

[12] Chellamma P, Sudhiraj, Vijayakumar A. Morbidity profile of sanitary workers in Thrissur corporation, Kerala. J Evolution Med Dent Sci 2015;4(89):15468-9.

[13] Khoshakhlagh A, Yazdaniraad S, Arvan M, et al. Evaluation of safety culture and work related accidents in oil depots of Tehran. Int J Occup Hyg 2017;9(1):9-14.

[14] Jeong BY, Lee S, Lee JD. Workplace accidents and workrelated illnesses of household waste collectors. Saf Health Work 2016;7(2):138-42.

[15] Abou-ElWafa HS, El-Bestar SF, El-Gilany $\mathrm{AH}$, et al. Musculoskeletal disorders among municipal solid waste collectors in Mansoura, Egypt: a cross-sectional study. BMJ Open 2012;2(5):e001338.

[16] Bulduk EO. Work-related stress levels and musculoskeletal disorders among municipal solid waste collectors in Ankara. Work 2019;63(3):427-33.

[17] Aweto HA, Adegbite KS, Owoeye OB. Work related musculosketal disorders in highway sanitary workers. Nigerian Journal of Medical Rehabilitation 2015;18(1).

[18] Mehrdad R, Majlessi-Nasr M, Amnian O, et al. Musculoskelatal disorders among municipal solid waste workers. Acta Medica Iranica 2008;46(3):233-8.

[19] Giri PA, Kasbe AM, Aras RY. A study on morbidity profile of sewage workers in Mumbai city. International Journal of Collaborative Research on Internal Medicine \& Public Health 2010;2(12):450-63.

[20] Rangamani S, Obalesha KB, Gaitonde R. Health issues of sanitation workers in a town in Karnataka: findings from a lay health monitoring study. Natl Med J India 2015;28(3):70-3.

[21] Jayakrishnan T, Jeeja MC, Bhaskar R. Occupational health problems of municipal solid waste workers in India. International Journal of Environmental Health Engineering 2013;2(3):24-30.

[22] Watt MM, Watt SJ, Seaton A. Episode of toxic gas exposure in sewer workers. Occup Environ Med 1997;54(4):27780.

[23] Mustajbegovic J, Zuskin E, Kern J, et al. Respiratory function in street cleaners and garbage collectors. Arh Hig Rada Toksikol 1994;45(3):241-8.
[24] Fahim AE, El-Prince M. Passive smoking, pulmonary function and bronchial hyper-responsiveness among indoor sanitary workers. Ind Health 2012;50(6):51620.

[25] Ibrahim MI, Djoharnis J, Shafei MN, et al. Respiratory symptoms and lung functions among domestic waste collectors: an experience in a developing country like Malaysia. International Journal of Collaborative Research on Internal Medicine \& Public Health, 2012;4(10):177584.

[26] Singh M, Ladusingh L. Factors associated with chronic bronchitis among municipal sanitary workers in Varanasi, India. Asian Journal of Epidemiology 2017;10:101-7.

[27] Thorn J, Beijer L, Rylander R. Work related symptoms among sewage workers: a nationwide survey in Sweden. Occup Environ Med 2002;59(8):562-6.

[28] Yan Y, Wang X, Wu J, et al. Occupational skin diseases and prevention among sanitation workers in China. Afr Health Sci 2015;15(3):768-75.

[29] Nethercott JR. Airborne irritant contact dermatitis due to sewage sludge. J Occup Med 1981;23:771-4.

[30] Sabde YD, Zodpey SP. A study of morbidity pattern in street sweepers: a cross-sectional study. Indian J Commun Med 2008;33(4):224-8.

[31] Ewis AA, Rahma MA, Mohamed ES, et al. Occupational health related morbidities among street sweepers and waste collectors at Beni-Suef, Egypt. Egyptian Journal of Occupational Medicine 2013;37(1):79-94.

[32] Karaman U, Atambay M, Aycan O, et al. Incidence of intestinal parasites in municipal sanitary workers in Malatya. Turkiye Parazitol Derg 2006;30(3):181-3.

[33] Chaudhry MA, Hyat A, Qureshi SM, et al. Health hazards of hospital waste to sanitary workers at combined military hospital Rawalpindi. Pak Armed Forces Med J 2004;54(2):253-8.

[34] Abd El-Wahab EW, Eassa SM, Lotfi SE, et al. Adverse health problems among municipality workers in Alexandria, Egypt. Int J Prev Med 2014;5(5):545-56.

[35] Pintakham K, Siriwong W. Health problems among street sweepers. IOSR J Environ Sci Toxicol Food Tech 2015;9(7):15-8.

[36] Jerie S. Occupational risks associated with solid waste management in the informal sector of Gweru, Zimbabwe. J Environ Public Health 2016;2016:1-14.

[37] Ivens UI, Hansen J, Breum NO, et al. Diarrhoea among waste collectors associated with bioaerosal exposure. Ann Agric Environ Med 1996;4:63-8.

[38] Indiana state department of health. Diseases Involving Sewage IN.gov.

[39] Sainath C, Ahmed KM. Occupational health hazards in sewage and sanitary workers. Indian Journal of Basic and Applied Medical Research 2014;3(4):31-5.

[40] Alam M. Frequency of hepatitis B \& C in adults seeking recruitment as sanitary workers. Pakistan Journal of Pathology 2011;22(2):80-1.

[41] Arvanitidou M, Constantinidis TC, Doutsos J, et al. Occupational hepatitis $B$ virus infection in sewage workers. Med Lav 1998;89(5):437-44.

[42] Ambekar AN, Bharadwaj RS, Joshi SA, et al. Sero sueveillance of leptospirosis among sewer workers in Pune. Indian J Public Health 2004;48(1):27-9. 
[43] Tiwari RR. Occupational health hazards in sewage and sanitary workers. Indian Journal of Occupational and Environmental Medicine 2008;12(3):112-5.

[44] Rajan D. Occupational stress among sanitary workers. International Journal of Business and Management Tomorrow 2012;2(9):1-14.

[45] Sophia NS, Pavithra S. A study on sanitation workers at Tiruchirapalli. International Journal of Applied Research 2017;3(4):168-70.

[46] Rajan D. Occupational stress among sanitary workers: a comparative analysis. International Journal of Applied Science and Engineering Research 2014;3(1):39-62.

[47] World bank group, World Health Organization, International Labour Organization and Water Aid. Health, Safety and Dignity of Sanitation Workers 2019:7-20.

[48] Rayen LP, Nisee TJ. A study on the problems of sanitary workers and its association with their profile variables. EPRA International Journal of Economic and Business Review 2017;5(12):140-6.

[49] Mitra R. Sanitation workers belonging to lower caste face social stigma: report. Express News Service 2019.

[50] Kuffour RA. Occupational health and safety challenges facing sanitary workers in Sekyere Central District in Ghana. Journal of Environmental and Occupational Science 2020;10(2):17-26.

[51] Soju A, Trivethi P, Prohit D. Occupational health issues of sewage and sanitary workers. An Official Newsletter of ENVIS-NIOH 2015;10(2):1-8.

[52] Vesper I. Dangers, health risks faced by sanitation workers exposed, the trust project. Bringing Science and Development Together Through News and Analysis 2019.

[53] JeyakrishnanT. Jeeja MC. Bhaskar R. Occupational health problems of Municipal solid waste workers in India. International Journal of Environmental Health Engineering, 2013;2(3):24-30.
[54] Allender JA, Rector CL, Warner KD. Community and public health nursing : promoting the public's health. 8th edn. Philadelphia: Lippincott Williams and Wilkins 2014:1030-5.

[55] Chen L, Zhang Y. Effect of comprehensive interventions on protective behaviours of sanitary workers against occupational exposure in hospitals. Modern Clinical Nursing 2015;44(5):41-3.

[56] Park K. Text book of preventive and social medicine. 24th edn. Jabalpur: Banarsidas Bhanot Publishers 2017:74862.

[57] Pawar VS. Right to health: a mirage for a municipal sanitary worker. Research Front 2014;2:67-70.

[58] Meena G. A study of quality of work life of sanitary workers. Studies in Indian Place Names 2020;40(71):755-62.

[59] Suryakantha AH. Community medicine with recent advances. $4^{\text {th }}$ edn. New Delhi: The Health Sciences Publisher 2017: p. 75.

[60] Anbarasu D, Narmadha S. Job promotion and attitudinal barrier of women sanitary workers. International Journal of Mutidiciplinary and Academic Research 2015;4(4).

[61] Selvamani R, Rajan D. Socio economic status of dalit women sanitary workers: a social work perspective. Indian Journal of Applied Research 2015;5(12):108-11.

[62] Lakshmi A, Paul CM, Thirunaaukarasu, et al. A cross sectional study on adoption of standard precautions among sanitary workers, Tamil Nadu. International Journal of Community Medicine and Public Health 2019;6(4):1442-5.

[63] Sexena RP. Textbook of community health nursing-II. Jalandhar: Lotus Publishers 3rd edn. 2020:196-206. 